\title{
PERANCANGAN ARSITEKTUR E-LEARNING DAN E-LIBRARY MENGGUNAKAN THE OPEN GROUP ARCHITECTURE FRAMEWORK- ARCHITECTURE DEVELOPMENT METHOD DI STKOM AL MA'SOEM BANDUNG
}

\author{
Tiffany Puspa Ramadhani \\ STKOM Al Ma'soem \\ pusparamadhani@gmail.com
}

\begin{abstract}
The concept of digital learning or e-learning is now widely applied in many universities. in this research is done architecture design of e-learning information system equipped with elibrary as storage media of material needed in learning and also as media of search of library material which amount is not limited. The background of this architectural design is two, which is less effective teaching and learning activities when there is holiday or lecturer absence and the last is the limited number of library materials in hardcopy. E-learning and e-library as one of the impacts of information technology advances can be utilized to overcome the obstacles in STKOM Al Ma'soem. With e-learning lecturers can provide lectures without having to face-toface with students. Whereas with the use of e-library students can get library materials online without limited space and time..
\end{abstract}

Keywords: E-leaning, E-library, The Open Group Architecture Framework (TOGAF)Architecture Development Method (ADM), Information System Architecture.

\begin{abstract}
ABSTRAK
Konsep pembelajaran digital atau e-learning kini sudah banyak diterapkan di banyak perguruan tinggi. dalam penelitian ini dilakukan perancangan arsitektur sistem informasi $e$ learning yang dilengkapi dengan e-library sebagai media penyimpanan materi yang dibutuhkan dalam pembelajaran dan juga sebagai media pencarian bahan pustaka yang jumlahnya tidak terbatas. Hal yang melatarbelakangi perancangan arsitektur ini ada dua, yaitu kurang efektifnya kegiatan belajar mengajar apabila terdapat tanggal merah ataupun ketidakhadiran dosen dan yang terakhir adalah terbatasnya jumlah bahan pustaka perpustakaan dalam bentuk hardcopy. E-learning dan e-library sebagai salah satu dampak kemajuan teknologi informasi dapat dimanfaatkan untuk mengatasi kendala yang ada di STKOM Al Ma'soem. Dengan e-learning dosen dapat memberikan perkuliahan tanpa harus bertatap muka secara langsung dengan mahasiswa. Sedangkan dengan pemanfaatan e-library mahasiswa dapat mendapatkan bahan pustaka secara online tanpa terbatas ruang dan waktu.
\end{abstract}

Kata Kunci : E-leaning, E-library, The Open Group Architecture Framework (TOGAF)Architecture Development Method (ADM), Arsitektur Sistem Informasi. 


\section{PENDAHULUAN}

\subsection{Latar Belakang Masalah}

Konsep pembelajaran dalam bentuk digital kini sudah banyak diterima oleh masyarakat, terbukti dengan maraknya implementasi e-learning di dunia pendidikan. $E$ learning adalah sistem pendidikan yang menggunakan aplikasi elektronik untuk mendukung pengembangan kegiatan belajar mengajar dengan media internet, intranet atau jaringan komputer lainnya.

E-learning memungkinkan terjadinya proses pendidikan tanpa harus melalui tatap muka secara langsung antara pendidik dan peserta didik. Melalui e-learning pengembangan ilmu pengetahuan kepada peserta didik dapat dilakukan dengan mudah tanpa ada batasan ruang dan waktu. Dalam e-learning dapat dimasukkan juga -library sebagai media penyimpan bahan materi yang dibutuhkan.

Sekolah Tinggi Komputer (STKOM) Al Ma'soem yang berada di kawasan pendidikan Jatinangor -Sumedang memiliki tiga program studi, yaitu Sistem Indormasi (SI), Sistem Informasi (D3), dan Sistem Informasi Akuntansi (D3). Walaupun namanya Sekolah Tinggi Komputer, namun dari hasil pengamatan terkait bidang pembelajaran dan sarana pendukung berupa buku-buku di perpustakaan belum seluruhnya memanfaatkan kemajuan teknologi informasi.

\subsection{Rumusan dan Batasan Masalah}

Berdasarkan permasalahan yang dikemukakan dalam latar belakang masalah, penulis membuat identifikasi masalah sebagai berikut:

1. Bagaimana merancang arsitektur sistem informasi e-learning dengan menggunakan framework TOGAF.

2. Bagaimana menyisipkan e-library pada sistem e-learning sebagai tambahan untuk tempat materi dosen dan bahan pustaka.

Dalam penelitian ini penulis membuat batasan sebagai berikut:

1. Dari sepuluh fase hanya delapan yang dibahas dalam Architectur Development Methode (ADM), yaitu:

a. Preliminary

b. Requirements management

c. Fase A : Architecture Vision.

d. Fase B :Bussiness Archi-tectuew

e. Fase C : Information System Architecture.

f. Fase D : Technology Archi-tecture.

g. Fase E : Opportunities and Solution.

h. Fase F : Migration Planning.

Dua fase yang tidak dibahas adalah fase $G$ (implementation Governance) dan fase $\mathrm{H}$ (Architecture Change Management)

2. Dokumen digital dalam e-library dibatasi hanya menggunakan format PDF (Portable Document File).

\subsection{Maksud dan Tujuan Penelitian}

Maksud dan tujuan dari penelitian ini adalah untuk merancang arsitektur e-learning dan e-Library menggunakan TOGAF-ADM di STKOM Al Ma'soem Bandung. Sedangkan tujuannya untuk :

1. Meningkatkan efektifitas kegiatan belajar mengajar dengan menggunakan teknologi informasi. 
2. Mengatasi keterbatasan tempat penyimpanan buku dalam bentuk hardcopy, sehingga mahasiswa bisa memanfatkannya tanpa terikat ruang dan waktu.

\subsection{Tinjauan Pustaka}

\subsubsection{Konsep Dasar Sistem Informasi}

Pada dasarnya terdapat dua kelompok pendekatan mengenai sistem, yaitu yang menekankan kepada prosedur dan pendekatan berdasarkan elemen atau komponen. Menurut Gerald (Ladjamudin, 2005) pengertian sistem dengan pendekatan kepada prosedur merupakan suatu jaringan kerja dari berbagai prosedur yang saling berinteraksi guna menyelesaikan suatu pekerjaan yang telah ditetapkan. Sedangkan penekanan kepada elemen atau komponen menurut Davis (Ladjamudin, 2005) sistem terdiri dari berbagai komponen yang saling berkaitan dan bekerja secara bersama guna mencapai tujuan tertentu. Ahli sistem lainnya yaitu Robert G. Murdick (Ladjamudin, 2005: 3) mengemukakan bahwa "sistem adalah seperangkat elemen-elemen yang terintegrasi dengan maksud yang sama untuk mencapai suatu tujuan bersama".

Seorang ahli informasi yaitu Burch dan Strater menyatakan bahwa "Informasi adalah pengumpulan atau pengolahan data untuk memberikan pengetahuan dan keterangan."John Burch dan Gary Grudnitski menggambarkan kualitas dari informasi dengan bentuk bangunan yang ditunjang oleh tiga buah pilar sebagaimana dapat dilihat dalam gambar 1 dibawah ini.

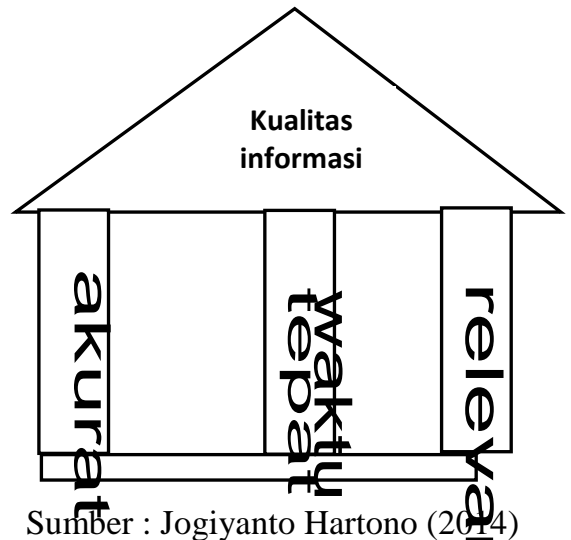

Gambar 1 Pilar Kualitas Informasi

\subsubsection{Arsitektur Enterprise}

Menurut Astha, dkk. (2013), Arsitektur Enterprise merupakan "Satu set spesifikasi model bisnis dan Teknologi Informasi (TI) yang merefleksikan integrasi enterprise dan kebutuhan standarisasi. Arsitektur enterprise mendefinisikan konteks integrasi bisnis data, proses, organisasi, teknologi dan menyelaraskan sumber daya enterprise dengan tujuan enterprise". Salah satu kerangka yang dapat digunakan untuk membangun arsitektur enterprise adalah menggunakan TOGAF (The Open Group Architecture Frame-work).

Arsitektur enterprise menyediakan pendekatan sistematis untuk mengelola aset sistem dan informasi serta mengarahkan kebutuhan strategi bisnis. Arsitektur enterprise mendukung pengambilan keputusan strategis dengan mem-bantu mengelola perubahan, mene-lusuri dampak perubahan organisasi dan bisnis terhadap sistem. Manfaat dari penggunaan arsitektur enterprise diantaranya:

1. Memungkinkan integrasi data, proses, teknologi dan usaha

2. Menyelaraskan sistem informasi dengan strategi bisnis

3. Memungkinkan penggunaan dan koordinasi sumberdaya yang lebih efektif

4. Mengembangkan komunikasi dan pemahaman dalam organisasi

5. Mengurangi biaya pengelolaan infrastruktur TI 
6. Mengarahkan perbaikan proses bisnis

7. Memungkinkan organisasi untuk merespon secara efektif terhadap perubahan peluang pasar dan tantangan industri. Arsitek-tur enterprise membantu mengevaluasi risiko bisnis, mengelola perubahan, meningkatkan efektivitas dan akuntabilitas bisnis.

\subsubsection{The Open Group Architecture Framework (TOGAF)}

Menurut Astha,dkk.(2013), TOGAF merupakan "Salah satu kerangka yang dapat digunakan untuk membangun sebuah arsitektur enterprise di dalam sebuah organisasi atau perusahaan. Singkatnya, arsitektur enterprise sama dengan rencana strategis, tetapi ruang lingkupnya adalah teknologi informasi dan TOGAF sendiri adalah panduan atau kerangka yang digunakan untuk membuat rencana strategis teknologi informasi tersebut". Metode yang digunakan pada framework TOGAF adalah Architecture Development Method (ADM).

\subsubsection{Architecture Development Method (ADM)}

Menurut Cecep Rachman(2012), ADM merupakan metode generik yang berisikan sekumpulan aktivitas yang digunakan dalam memodelkan pengembangan arsitektur enterprise. Metode ini juga bisa digunakan sebagai panduan atau alat untuk merencanakan, merancang, mengembangkan dan mengimplementasikan arsitektur sistem informasi untuk organisasi. Sedangkan kerangka kerja dari Arcitecture Development Method (ADM) pada TOGAF dapat dilihat pada tabel 1 dibawah ini.

Tabel 1 Kerangka kerja ADM pada TOGAF 9.1

\begin{tabular}{|c|c|c|c|}
\hline $\begin{array}{l}\text { Prefiminary Phase } \\
\text { Plinciples catalog }\end{array}$ & $\begin{array}{l}\text { Phase A, Architecture Vision } \\
\text { - Stakehoider Map Matrix . }\end{array}$ & Solution Concept dagram & \multirow[t]{2}{*}{ - Value Chain clagram } \\
\hline Requirements Menagement & Requirements cataog & & \\
\hline 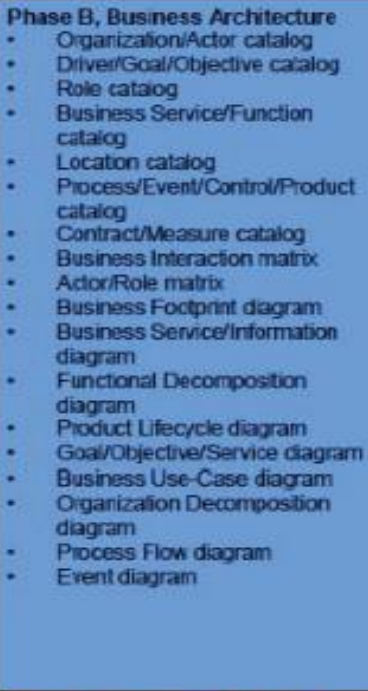 & $\begin{array}{l}\text { Phase C, Data } \\
\text { Architecture } \\
\text { - Data Entity Data } \\
\text { Component catalog } \\
\text { - } \text { Data Entit/Business } \\
\text { Functon matrix } \\
\text { - AfplicationData } \\
\text { matrix } \\
\text { Logica Data } \\
\text { diagram } \\
\text { Data Dissemination } \\
\text { diagram } \\
\text { - Data Security } \\
\text { diagram } \\
\text { Class Hierarcity } \\
\text { diagram } \\
\text { Data Migration } \\
\text { diagran } \\
\text { Dita Lifecycle } \\
\text { diagram }\end{array}$ & 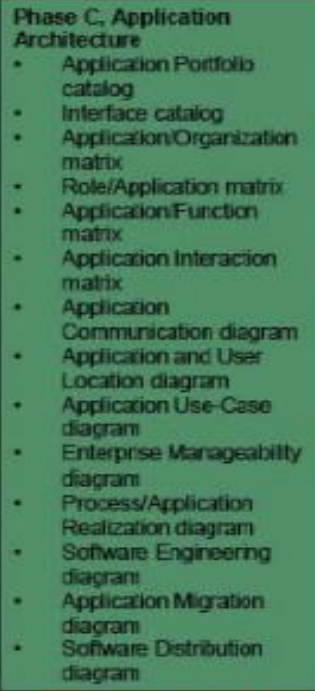 & $\begin{array}{l}\text { Phase D, Technology } \\
\text { Architecture } \\
\text { Technology } \\
\text { Standards catalog } \\
\text { Technolog/ Portfolio } \\
\text { catalog } \\
\text { System/Technology } \\
\text { matrix } \\
\text { Environments and } \\
\text { Locations degram } \\
\text { Platform } \\
\text { Decornposition } \\
\text { diagram } \\
\text { Processing diagram } \\
\text { Netwoiked } \\
\text { Computing/Hardware } \\
\text { diagran } \\
\text { Communications } \\
\text { Engineering dagram }\end{array}$ \\
\hline $\begin{array}{l}\text { Phase E. Opportunitios \& Solutic } \\
\text { Project Context ciagram } \\
\text { Benefits eagam }\end{array}$ & & & \\
\hline
\end{tabular}

\subsubsection{Unified Modelling Language (UML)}

Unified Modelling Language (UML) adalah keluarga notasi grafis yang didukung oleh model-model tunggal yang membantu pendeskripsian dan desain perangkat lunak, khususnya sistem yang dibangun menggunakan pemograman berorientasi objek. Alat yang digunakan meliputi: Use Case Diagram, Class Diagram, Sequence Diagram, dan Activity Diagram.

\subsubsection{Porter Five Forces}


Menurut Team FME (2013), Porter Five Forces adalah Lima kekuatan utama yang ditemukan oleh Michael E. Porter pada tahun 1979 yang dapat menentukan daya tarik mendasar suatu pasar dalam jangka panjang. Model Porter mempertimbangkan lima kekuatan (Five forces) yang menentukan 'daya tarik' pasar dengan menganalisis intensitas pesaing. Yang dimaksudkan dengan suatu pasar yang 'menarik' yaitu keuntungan industri secara keseluruhan yang dinilai dengan melihat potensi peluang dan resiko.

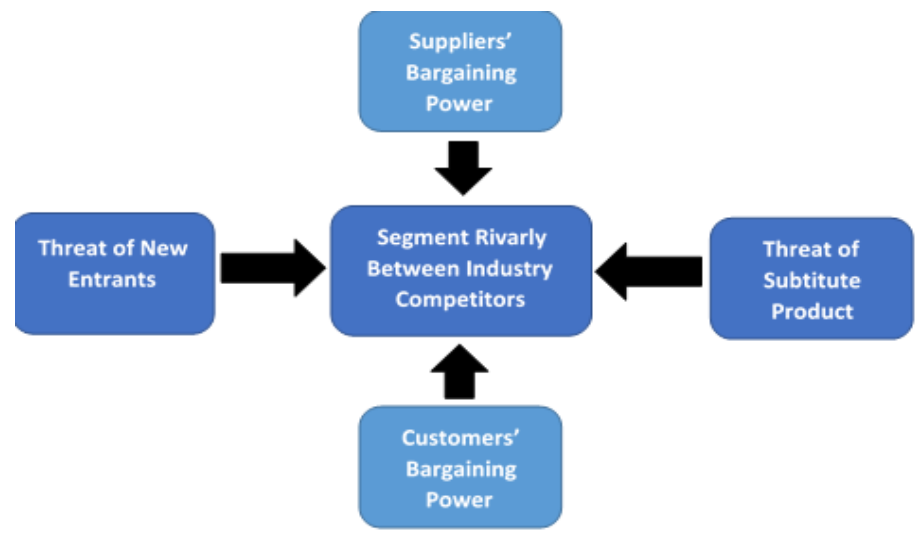

Gambar 2 Porter Five Forces

\subsubsection{Analisis SWOT}

Menurut Team FME (2013), analisis SWOT adalah teknis analisis bisnis yang dapat digunakan organisasi untuk menentukan produk, pelayanan dan pasar guna menemukan cara terbaik untuk mencapai pertumbuhan di masa mendatang. Prosesnya melibatkan identifikasi kekuatan (srength) dan kelemahan (weakness) dari orga-nisasi dan peluang (opportunities) serta ancaman (threat) yang ada bagi organisasi.

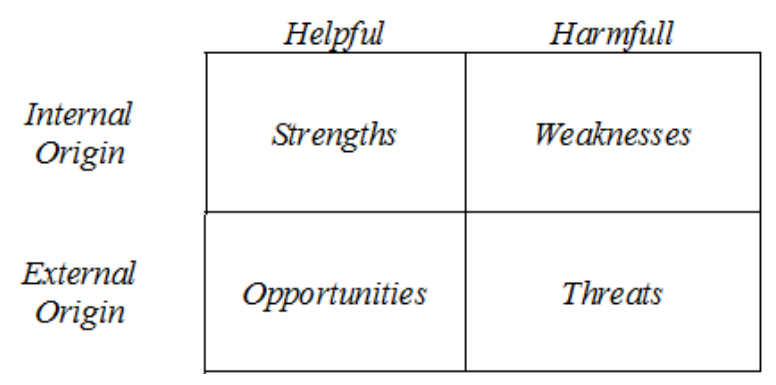

Gambar 3 Tabel Analisis SWOT

\subsubsection{Value Chain}

Menurut Forda Gigih(2013), Value chain (rantai nilai) dapat dijadikan sebagai langkah awal dalam memodelkan bisnis dengan mendefinisikan area fungsional utama dan area pendukung. Rantai nilai Porter yang terdiri dari aktifitas utama (Primary activity) dan aktifitas pendukung (Support activity). 


\section{METODOLOGI}

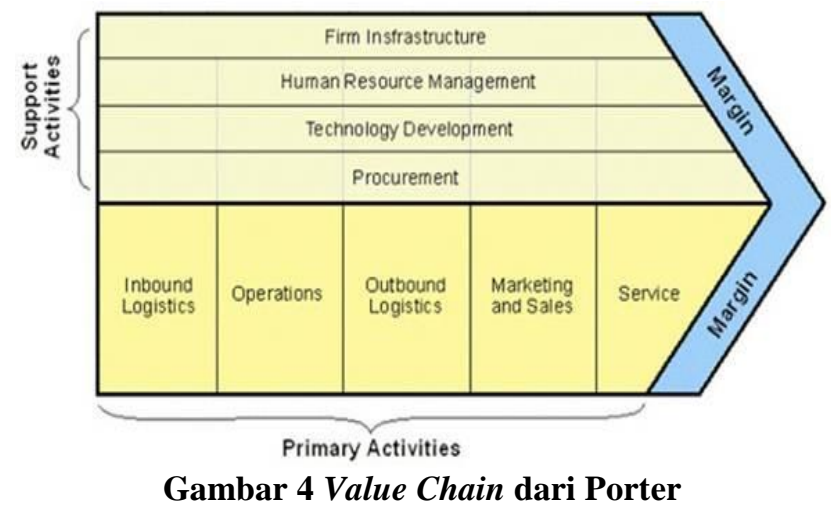

Metode yang digunakan dalam penelitian ini yaitu dengan menggunakan TOGAFADM. Dari tahapan yang ada, penulis menggunakan tahap satu sampai delapan (tahap sembilan dan sepuluh tidak dilakukan). Tahapan-tahapan yang ada dalam Arcitecture Development Method (ADM) sebagai berikut :

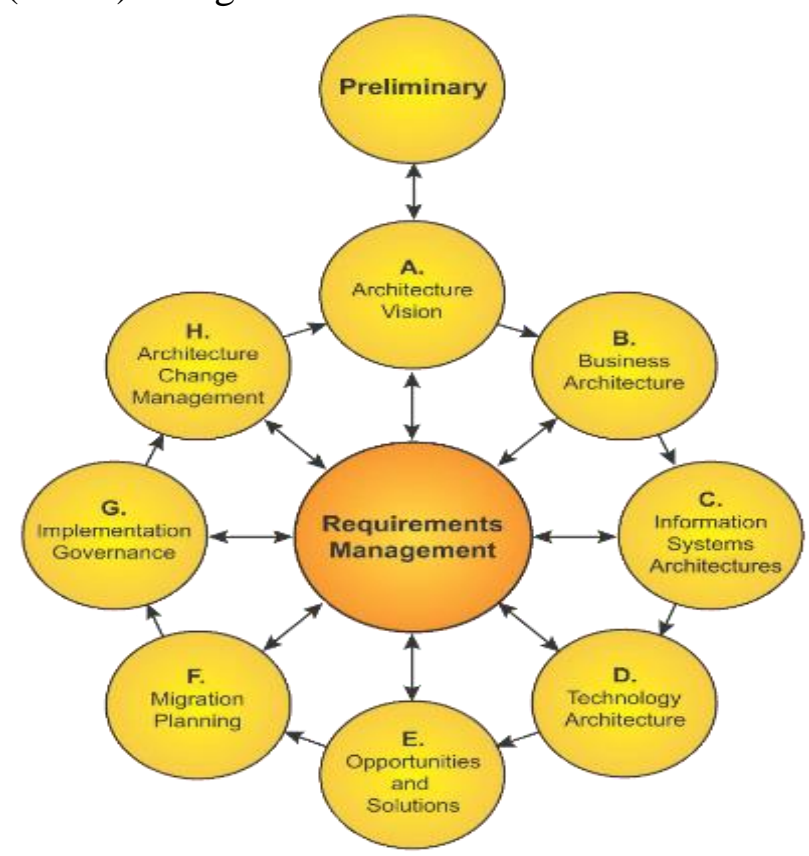

Gambar 5 Architecture Development Method

Keterangan :

1. Fase Preliminary.

Pada fase ini dilakukan perencanaan dengan baik atas keseluruhan arsitektur yang akan dibangun berdasarkan kebutuhan, proses dan perkiraan keburuhan mendatang.

2. Fase Requirement Management.

Pada fase ini dilakukan penggalian kebutuhan (require-ments) organisasi serta mendokumentasikan kebutuhan pengguna. Tujuan fase ini untuk menyediakan proses pengelolaan kebutuhan arsitektur sepanjang fase pada siklus ADM, mengidentifikasikan enterprise, menyimpan lalu memberikannya pada fase yang relevan.

3. Fase A : Architecture Vision

Pada fase ini dilakukan penetuan akan visi dari arsitektur yang akan dibangun.

4. Fase B :Bussiness Architecture

Pada fase ini dilakukan pendefinisian kondisi awal arsitektur bisnis. Pada fase ini juga dilakukan pemodelan bisnis dengan memilih tool yang tepat untuk menggambarkan arsitektur bisnis. 
5. Fase C : Information System Architecture

Fase ini menekankan pada bagaimana arsitektur sistem informasi dibangun yang meliputi arsitektur data dan arsitektur aplikasi yang akan digunakan oleh organisasi. Tekhnik yang dapat digunakan dapat berupa ER-diagram, class diagram dan object diagram.

6. Fase D : Technology Archytecture

Pada fase ini didefinisikan kebutuhan teknologi yuntuk mengolah data. Langkah awal yang dilakukan adalah menentukan kandidat teknologi yang akan digunakan untuk menghasilkan pemilihan teknologi untuk platform teknologi yang ada dalam aplikasi perangkat lunak dan perangkat keras.

7. Fase E : Opportunities and Solution

Fase ini menekankan pada manfaat yang diperoleh dari arsitektur enterprise. Dilakukan evaluasi gap dari arsitektur enterprise yang meliputi arsitektur bisnis, data, arsitektur aplikasi dan arsitektur teknologi untuk selanjutnya membuat strategi untuk solusi.

8. Fase F : Migration Planning

Pada fase ini dilakukan penilaian dalam menentukan rencana migrasi dari suau sistem informasi. Penilaian itu lalu diurutkan berdasarkan prioritas yang selanjutnya menjadi dasar rencana untuk penerapan dan migrasi.

9. Fase $\mathrm{G}$ : Implementation Governance

Pada fase ini dilakukan penyusunan rekomendasi untuk pelak-sanaan tata kelola penerapan yang sudah dilakukan. Tata kelola tersebut meliputi tata kelola teknologi informasi dan tata kelola arsitektur.

10. Fase H : Architecture Change Management

Pada fase ini ditetapkan rencana pengelolaan arsitektur dari sistem baru yang sedang berjalan dengan cara melakukan pengawasan terhadap pengembangan teknologi dan perubahan lingkungan organisasi.

\section{ANALISA DAN PERANCANGAN SISTEM}

\subsection{Analisis Kebutuhan}

Analisa kebutuhan terdiri dari analisis Five Forces Porter, analisis SWOT, dan analisis Value Chainyang akan dijelaskan sebagai berikut :

1. Analisis Five Forces Porter

Berdasarkan lima kekuatan utama dalam model Porter (Five Forces Porter) penulis menggambarkan sebuah diagram analisis persaingan bisnis e-learning dari STKOM Al Ma'soem pada gambar 6 dibawah ini. 


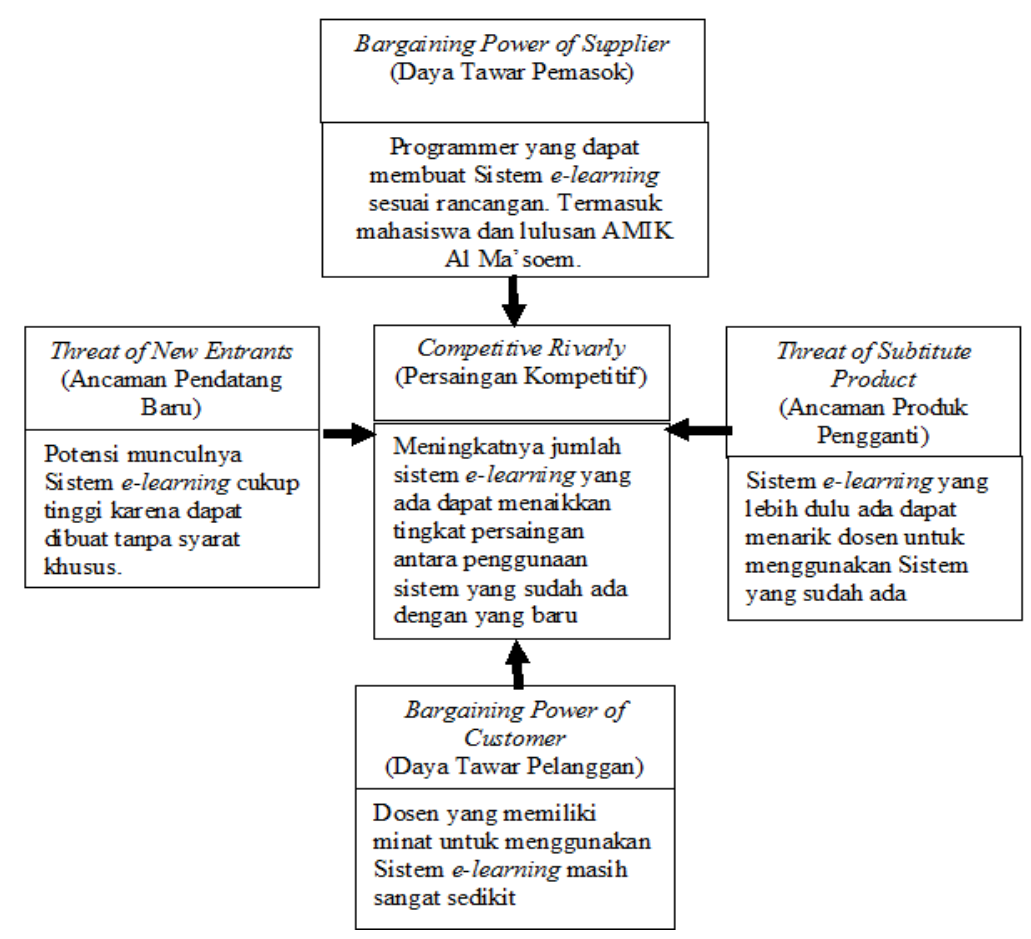

Gambar 6 Diagram Five Forces Porter STKOM Al Ma'soem

\section{Analisis SWOT}

Setelah melakukan analisis SWOT, didapatkan alternatif strategi yang dapat digunakan berdasarkan gabungan opportunities dan strength, opportunities dan weakness, threat dan strength, dan terakhir threat dan weakness.

Tabel 2 Alternatif Strategi

\begin{tabular}{|c|c|c|}
\hline & Strength & Weakness \\
\hline \multirow[b]{2}{*}{ 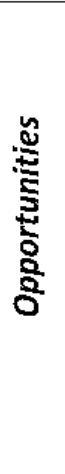 } & OS & OW \\
\hline & $\begin{array}{l}\text { 1. Membangun sistem } \\
\text { pembelajaran yang bersifat } \\
\text { e-Learning } \\
\text { 2. Segera menerapkan sistem } \\
\text { e-Library sehingga semua } \\
\text { civitas dapat mengakses } \\
\text { berbagai bahan pustaka } \\
\text { tanpa harus datang ke } \\
\text { perpustakaan } \\
\text { TS }\end{array}$ & $\begin{array}{l}\text { 1. Membangun sistem e-Learning } \\
\text { untuk melengkapi sistem } \\
\text { pembelajaran yang sudah ada } \\
\text { 2. Membangun sistem e-Library } \\
\text { guna menunjang sistem e- } \\
\text { Learning }\end{array}$ \\
\hline 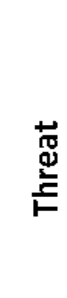 & $\begin{array}{l}\text { Segera membangun e- } \\
\text { Learning dan e-Library }\end{array}$ & $\begin{array}{l}\text { 1. Melengkapi sistem } \\
\text { pembelajaran yang ada } \\
\text { sekarang dngan e-Learning } \\
\text { 2. Melengkapi perpustakaan yang } \\
\text { ada dengan sistem e-Library }\end{array}$ \\
\hline
\end{tabular}

3. Analisis Value Chain 
Sesuai dengan tema penelitian yang digunakan penulis, Value chain STKOM Al Ma'soem dapat dilihat pada gambar 7 dibawah ini.

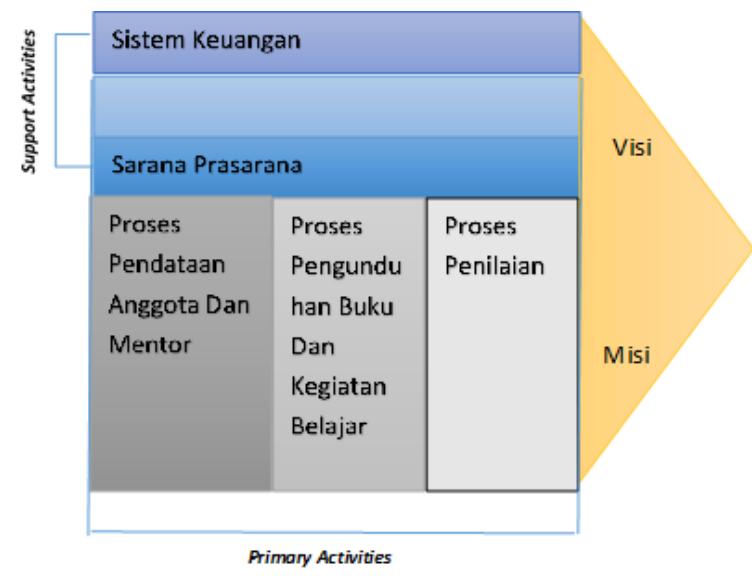

Gambar 7 Value Chain STKOM Al Ma'soem

\subsection{Perancangan dan Implementasi}

Tahap perancangan dan implementasi akan dijelaskan sebagai berikut :

1. Use Case dan Class Diagram

Use Case merupakan aktivitas bisnis yang melibatkan peranan pemakai dengan sistem yang akan digunakan. 


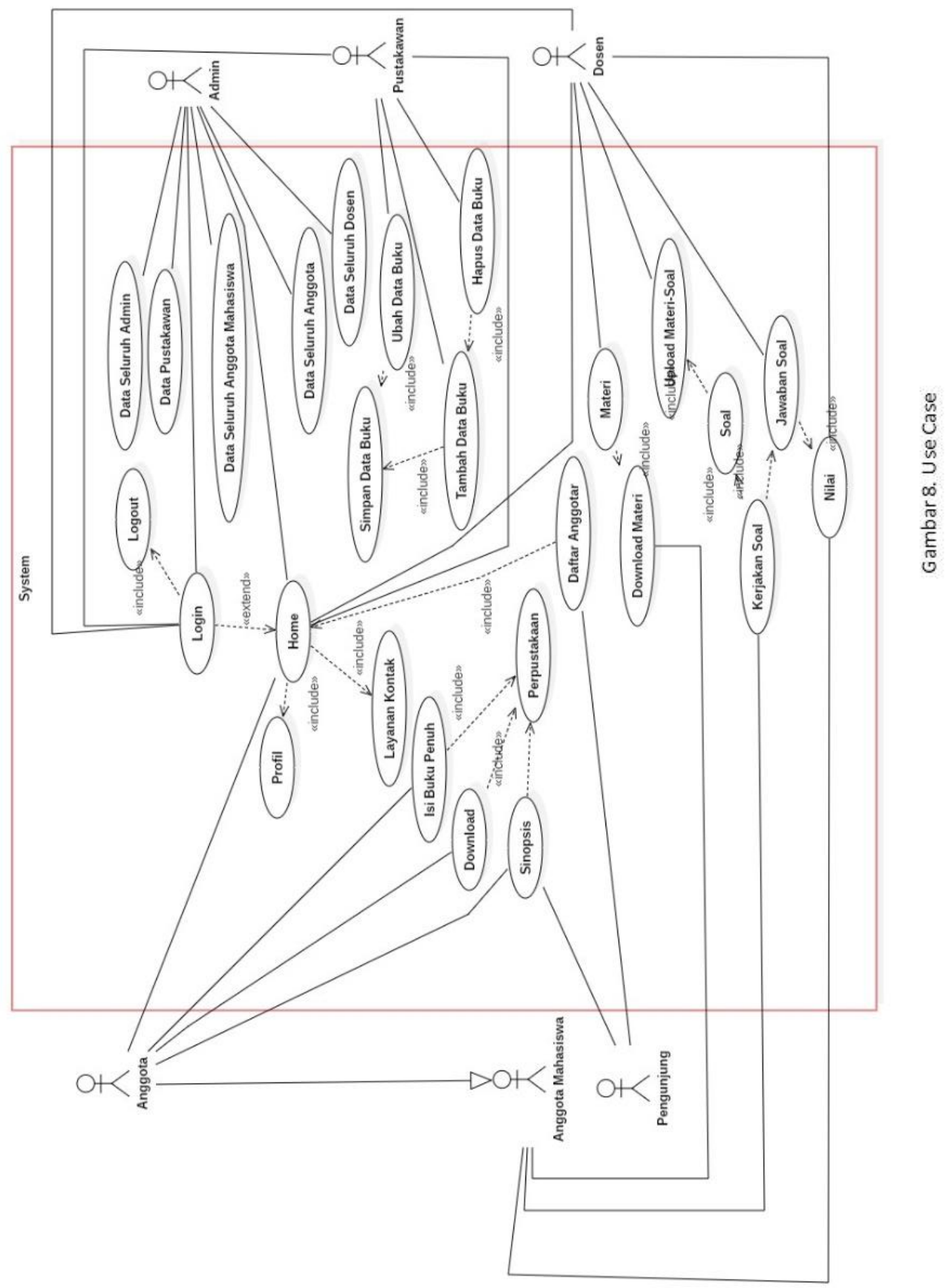





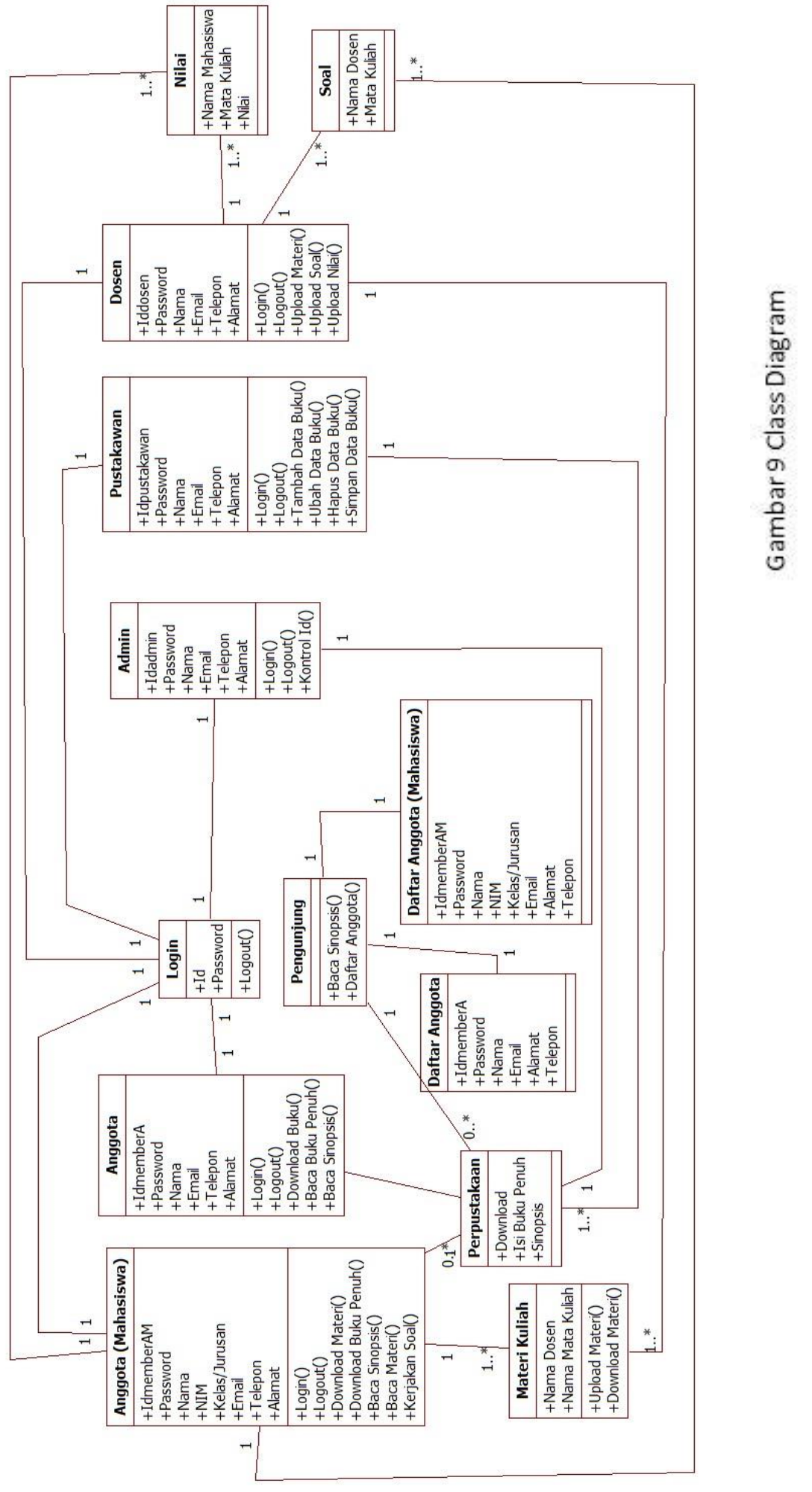


2. Arsitektur Aplikasi

Berdasarkan ilustrasi yang digambarkan oleh gambar 10, data dapat diinput dari dua perangkat alat input yang terhubung dengan koneksi internet. Data bisa diinput melalui personal computer (PC) ataupun laptop. Kemudian data tersebut diproses menjadi menjadi sebuah database sistem e-learning dan e-library. Berdasarkan proses tersebut, data bisa menghasilkan informasi yang dibutuhkan oleh para stakeholder, dimana informasi (output) tersebut ditampilkan melalui aplikasi sebagai hasil pengolahan sistem.

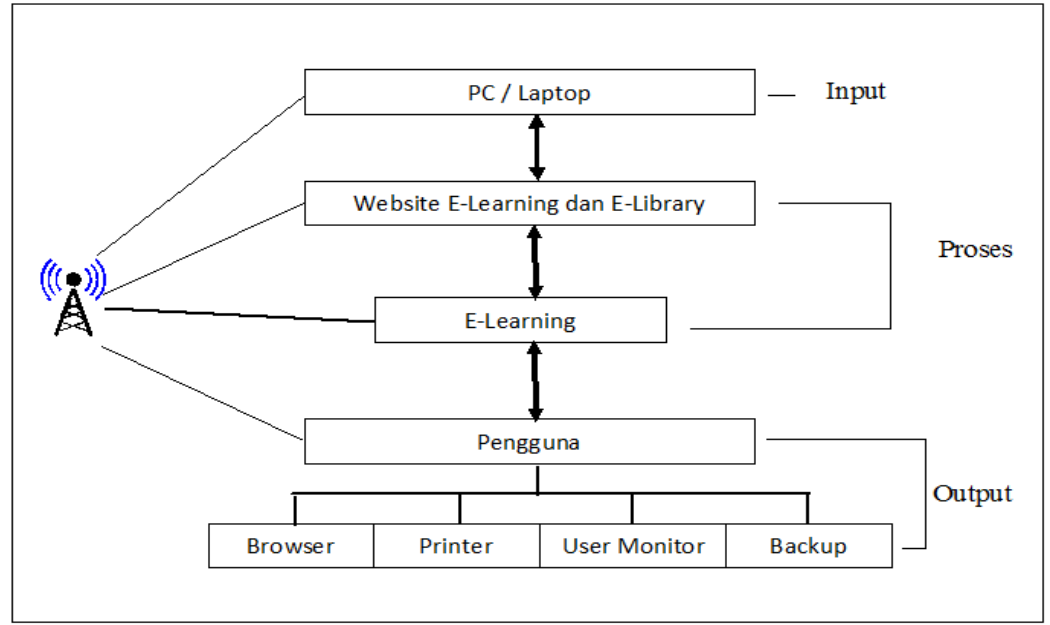

Gambar 10 Arsitektur Aplikasi Sistem e-learning dan e-library STKOM Al Ma'soem

3. Arsitektur Teknologi

Berikut adalah usulan arsitektur jaringan pada gambar berikut ini.

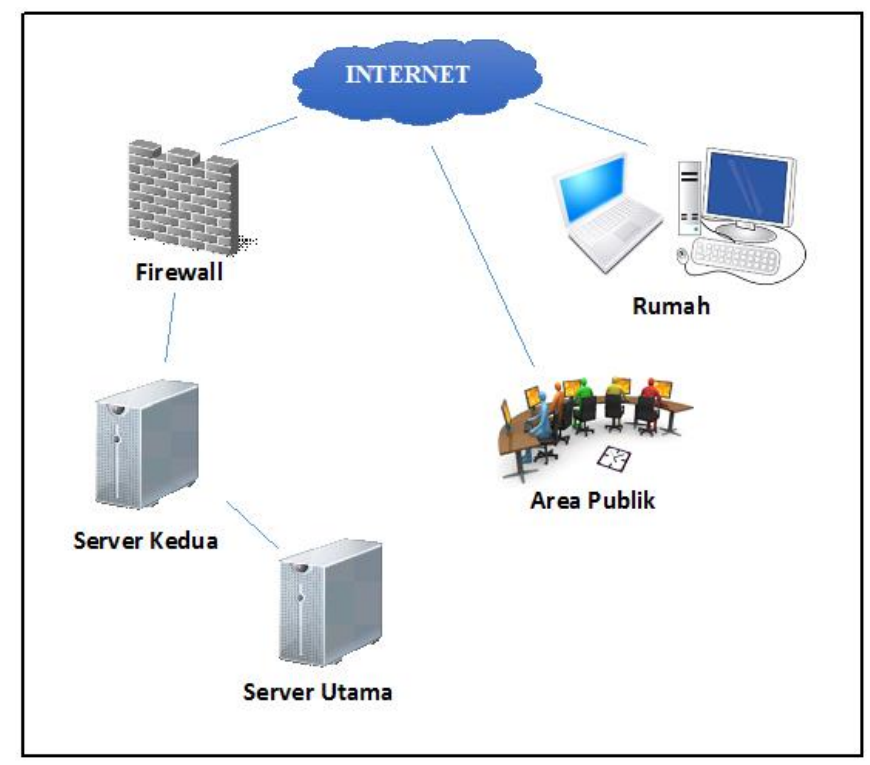

Gambar 11 Arsitektur Jaringan Usulan 
Situs dapat dibuka melalui komputer pribadi maupun layanan publik dengan syarat memiliki koneksi internet. Situs berasal dari server utama dan server kedua yang terlebih dahulu dilindungi oleh firewall.

\section{PENUTUP}

\subsection{Kesimpulan}

Pada bab-bab sebelumnya telah dijelaskan hasil dari penelitian yang menyangkut halhal tentang pembelajaran dan perpustakaan digital (e-learning dan e-library). Maka dari itu dapat disimpulkan bahwa dengan dibuatnya sistem baru ini :

1. Kegiatan belajar mengajar di STKOM Al Ma'soem tidak terpaku kepada pembelajaran tatap muka, tapi dapat dilakukan setiap saat dengan $e$-learning tanpa perlu bertemu dalam ruangan yang sama selama koneksi internet tersedia. Ketidakhadiran dosen atau hari libur bukan hambatan terhentinya kegiatan pembelajaran. Hambatan pembelajaran konvensional diatas dengan merancang sistem pembelajaran e-learning dengan framework TOGAF dan metode ADM.

2. Tambahan e-library dimaksudkan untuk menyimpan materi yang dibutuhkan dalam kegiatan belajar mengajar (e-learning) dan juga sebagai media pencarian bahan pustaka dengan satu judul buku yang dapat diunduh dengan jumlah tak terbatas.

\section{DAFTAR PUSTAKA}

Al-Bahra, Bin Ladjamudin. (2005). Analisis Dan Desain Sistem Informasi.Yogyakarta: Graha Ilmu.

Astha, Andi Muhammad Alif Dipo. (2013). The Open Group Architecture Framework (TOGAF).

Forda, Gigih. (2013). Perancangan Infrastruktur Teknologi Informasi Adaptif Pada Universitas Lampung. Karya akhir pada Fakultas Ilmu Komputer Universitas Indonesia Jakarta : Tidak diterbitkan.

Hartono, Jogiyanto. (2014). Analisis Dan Desain Sistem Informasi. Yogyakarta:Andi.

Jatnika, Hendra. (2013). Sistem Informasi Manajemen Berbasis Komputer.Yogyakarta : Andi.

Mardiansyah, Cecep Rachman. (2012). Analisis Dan Pengembangan Enterprise Arsitektur Menggunakan Framework TOGAF Pada Pengadilan Agama Bandung. Tugas akhir pada Program Studi Sistem Informasi Fakultas Teknik Universitas Widyatama Bandung : Tidak diterbitkan.

Team FME. (2013). Porter's Five Forces Strategy Skill. E-book.Tidak diterbitkan.

Team FME. (2013). SWOT Analysis Strategy Skill. E-book. Tidak diterbitkan. 